\title{
Does englacial water storage drive temperate glacier surges?
}

\author{
Craig S. Lingle, ${ }^{1}$ Dennis R. FATLAND ${ }^{2}$ \\ ${ }^{1}$ Geophysical Institute, University of Alaska Fairbanks, 903 Koyukuk Drive, Fairbanks, AK 99775-7320, U.S.A. \\ E-mail: clingle@gi.alaska.edu \\ ${ }^{2}$ Vexcel Corporation, 4909 Nautilus Court, Boulder, CO 80301-3242, U.S.A.
}

\begin{abstract}
Hydrological studies of surge-type and steady-flow glaciers, combined with recent space-borne synthetic aperture radar interferometry measurements of the motion of Bagley Ice Valley, Alaska, U.S.A., during its 1993-95 surge, suggest a temperate-glacier surge hypothesis that is consistent with observational evidence and appears capable of shedding light on several aspects of surge behavior. We propose that the fundamental driver of temperate-glacier surges is englacial storage of water, combined with gravity-driven movement of stored water to the bed during winter. Whether a given glacier is surge-type is a matter not of whether, but of the degree to which, these processes occur. A surge-type glacier must have sufficient storage capacity for continued downward movement of englacially stored water during winter to finally overwhelm the constricted basal drainage system, thereby forcing pervasive failure of the subglacial till - or, alternatively, widespread and rapid basal sliding - thus initiating a surge. We further propose that the "sufficient storage capacity" requirement is most easily met by glaciers with large thickness, which are therefore likely to be long and to have, on average, low surface slopes. The average leng th of the surge cycle in a given region appears to be a function of the mass balances, which, after each surge, determine the time required to restore glaciers to their pre-surge geometries. We suggest that the stochastic timing of surge onset for a particular glacier, however, is a result of the uncertainty of the meteorological conditions required to cause englacial storage of a sufficiently large volume of water.
\end{abstract}

\section{INTRODUGTION}

The 1993-95 surge of Bering Glacier and Bagley Ice Valley (formerly Bagley Icefield), Alaska, U.S.A. (Fig. 1), which occurred soon after the 1991 launch of the First European Remote-sensing Satellite (ERS-1), provided a unique opportunity to employ space-borne synthetic aperture radar (SAR) imagery for observation and analysis of this major surge, which affected virtually the entire $180 \mathrm{~km}$ length of the largest glacier in continental North America (Molnia and Post, 1995; Fatland, 1998; Fatland and Lingle, 1998, 2002; Roush and others, 2003). SAR enabled observation of Bagley Ice Valley during the winter months when extended darkness, cold, and heavy snow effectively precluded data acquisition by other means. In particular, the winter "ice phases" of ERS-1, with 3 day exact-repeat orbit cycles, enabled detailed measurement of the surface motions of Bagley Ice Valley using SAR interferometry during mid-winter 1993/94, while the surge was in full progress (Fatland, 1998; Fatland and Lingle, 1998, 2002). These mid-winter observations, combined with earlier work by others on glacier hydrology and surge mechanics (e.g. Kamb and others, 1985; Clarke and others, 1986; Kamb, 1987; Raymond, 1987; Fountain and Walder, 1998), suggest a hypothesis that appears capable of shedding light on several aspects of glacier surging. Fundamental to this hypothesis are the observations first published by Stenborg (1970), Björnsson (1972) and Tangborn and others (1975), which led to the conclusion that temperate glaciers store water. This conclusion has been substantiated by more recent observations (e.g. Collins, 1982; Willis and others, 1993; Murray and others, 2000).

\section{ENGLAGIAL WATER STORAGE}

Stenborg (1970), who carried out hydrological and other related measurements on Mikkaglaciären, northern Sweden, from 1 June to 1 September 1957, found that the runoff excess during mid-summer was greater than the runoff deficit during early summer by about a factor of two (see table on p. 24 of Stenborg, 1970). He concluded that the glacier had

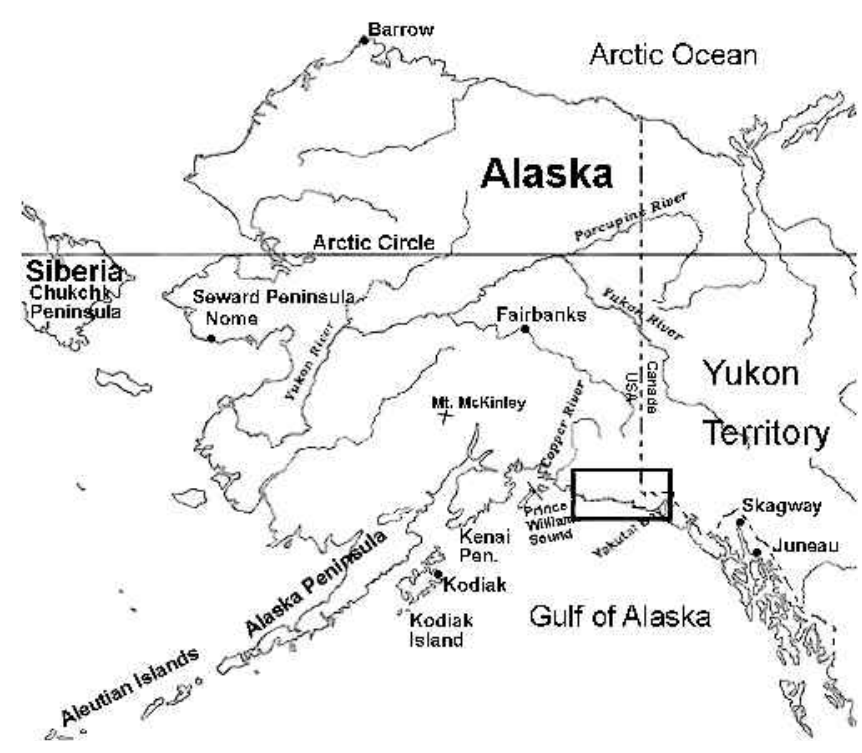

Fig. 1. The box shows the location of Bering Glacier and Bagley Ice Valley. Upper Seward Glacier (Fig. 4a and $b$ ) is located near the east (right) border of the box. 
stored water during early summer and subsequently released this stored water during mid-summer. His data suggest that additional storage probably occurred during the preceding spring and, possibly, autumn and winter. Björnsson (1972) found evidence of delayed runoff due to water storage by Bægisárjökull in northern Iceland.

Tangborn and others (1975) estimated the mass balance of South Cascade Glacier, in Washington, U.S.A., by three different methods including the hydrological method. Their observations extended from 1 May to 30 September 1965-70. They found that the water volumes released during summer as runoff greatly exceeded the volumes that could be attributed to ablation plus rainfall; the difference was so large it could not be attributed to measurement errors. They concluded that from 1 May to 19 June, water went into storage. From 20 June to 30 September, a volume of water about seven times greater than the volume that apparently went into storage was drained from storage and discharged as runoff. This large difference suggests that additional water went into storage prior to 1 May.

Tangborn and others (1975) concluded that during long periods with little or no ablation (late fall to early spring), the glacier's internal and subglacial drainage system becomes constricted. The water resulting from the relatively small amounts of ablation and rain occurring during these periods is thus forced into storage. When ablation increases in the spring, the rapidly increasing hydraulic head forces additional water into storage while the summer drainage system is gradually melting open. Much of the runoff observed during summer was thus stored during the preceding spring and fall.

Fountain (1989) showed that the firn on South Cascade Glacier also accounts for significant water storage, with about $12 \%$ of the total spring storage being within the firn layer.

More recent studies (e.g. Collins, 1982; Willis and others, 1993) have substantiated seasonal water storage by temperate glaciers, with maximum filling and release occurring during varying time periods. Willis and others (1993), for instance, found that filling of Midtdalsbreen, Norway, continued until late July; this was followed by a period of balance, then another period of filling during August, such that maximum water storage occurred in late August.

Fountain and Walder (1998) suggest that the likely storage capacity of subglacial cavities beneath small, temperate alpine glaciers (e.g. South Cascade Glacier) is insufficient to account for the estimated volumes of stored water. This implies that most water storage may be englacial. Considering this problem in greater detail, these authors concluded, by process of elimination, that "a substantial fraction of both short- and longterm water storage is probably englacial”.

Murray and others (2000) found, from measurements of radar propagation velocity vs depth, that the englacial water content of Falljökull, Iceland, (in the ablation area, near the terminus) was equivalent to a layer of water at least $1.8 \mathrm{~m}$ thick per square meter of basal area, and that this water was stored within veins and cavities significantly smaller than the resolution of the radar, which was of the order of a few tens of centimeters.

\section{A STORAGE MEGHANISM, WINTER WATER, AND BASAL MOTION}

A comparative study of the hydrology of surge-type Black
Rapids Glacier and nearby steady-flow Fels Glacier, in the Alaska Range, was carried out by Raymond and others (1995). The period of observation was about mid-May through mid-August 1986-89. The authors concluded that the drainage systems of these glaciers could be viewed as consisting of slow systems, which carried about $80-90 \%$ of the water, and superimposed fast systems which carried the remaining $10-20 \%$. The fast systems were restricted to the lowermost $30-40 \%$ of the glacier length (within the ablation areas), and consisted of discharge routes (surface streams, moulins and subglacial conduits) that transported water quickly and responded to diurnal variations in water input caused, for example, by surface temperature changes and rainfall. The slow systems, which did not respond to diurnal variations in water input, were described by these authors as consisting of "heterogeneous small passageways throughout the ice and distributed at the bed, which maintained relatively uniform discharge from day to day".

Black Rapids and Fels Glaciers were found by Raymond and others (1995) to be "hydrologically normal" relative to other temperate glaciers (e.g. Röthlisberger and Lang, 1987). That is, the surge-type character of Black Rapids Glacier could not be distinguished from the steady-flow character of Fels Glacier based on the hydrological measurements. The hydrology of Black Rapids Glacier is not necessarily typical of all surge-type glaciers in Alaska and Yukon; Trapridge Glacier, for example, may have characteristics more typical of surge-type glaciers on the inland side of the Saint Elias Mountains, Yukon Territory, Canada (see Clarke and others, 1984; Flowers and Clarke, 1999; Flowers, 2000; see also Björnsson, 1998, for an unusual example of subglacial hydrology during an Icelandic surge). The finding that Black Rapids and Fels Glaciers could not be distinguished on the basis of their hydrological characteristics, however, is significant.

The slow drainage systems that existed throughout Black Rapids and Fels Glaciers, in particular throughout the upper $60-70 \%$ of their lengths, which contained an estimated 80 $90 \%$ of the water at any given time during summer, may act as water-storage elements in late summer and early autumn. That is, at the end of the summer melt season, constriction of the relatively narrow passageways of the slow systems, due to reduced water flux, may effectively trap large quantities of water within these glaciers. The relatively small amounts of additional water resulting from occasional ablation and rain during this time period (as suggested by Tangborn and others, 1975) would then add to the amount of stored water. In addition, water stored within the firn layer at the end of summer very likely drains into the glacier during the subsequent winter, thus adding to englacial storage and, ultimately, to the amount of water reaching the bed (Fountain, 1989). Simultaneously, the relatively small amounts of water (about 10-20\% of the total) remaining within the fast system may drain out to the terminus and be lost as runoff during late summer and early fall, since there is evidently nothing to prevent this.

In April 1996, seven holes were drilled to depths of about $600 \mathrm{~m}$ in Black Rapids Glacier by W. D. Harrison, M. Truffer, K. A. Echelmeyer and others (personal communication, 1997), in preparation for the work described by Truffer and others (1999). The early-spring time period of this project was within hydrological winter, so surface melting had not yet begun. A large volume of water was pumped from one hole to determine whether it had connected with the subglacial water system, using a high-capacity pump. The pump 


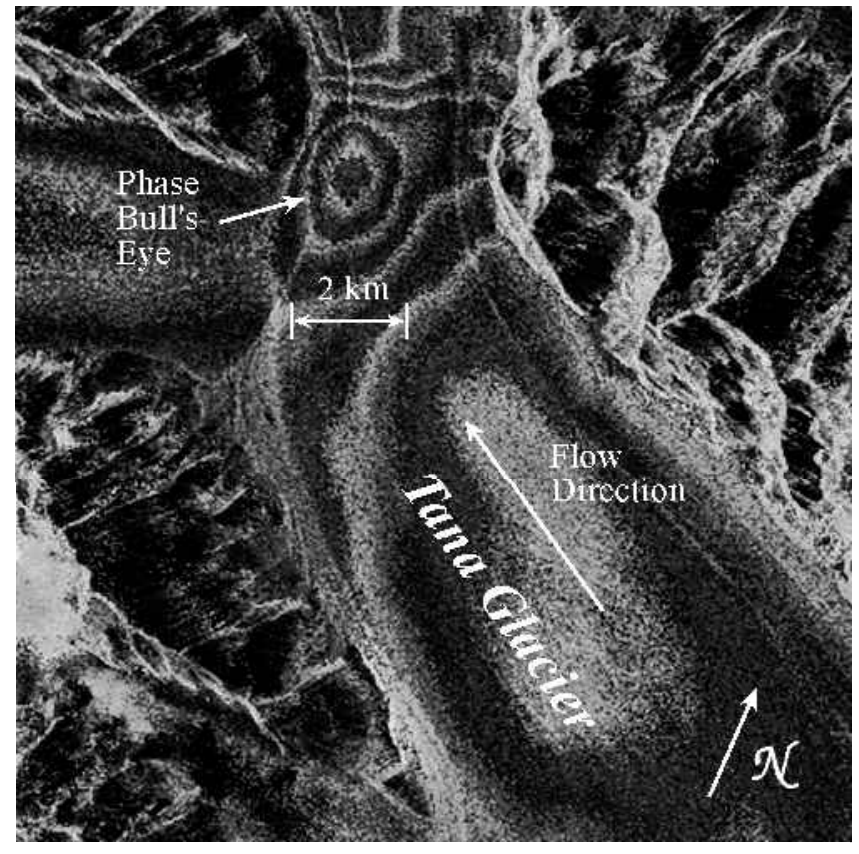

Fig. 2. A winter phase bull's-eye (lower of the two near top center) observed on Tana Glacier (Fig. 3), which is a Bering Glacier distributary that did not participate in the 1993-95 surge of Bering Glacier and Bagley Ice Valley. Negative phase curvature indicates downward displacement of the surface. Note that concurrent upward displacement of the surface is indicated by positive phase curvature of the bull's-eye at top center, suggesting simultaneous drainage and emplacement of subglacial water beneath this up-and down-glacier phase bull's-eyes couplet. was incapable of lowering the water level, which was close enough to the surface to indicate subglacial water pressure within about $90 \%$ of the ice overburden pressure. All of the water was then pumped back into the hole, again with no effect on the water level. The implied subglacial water pressure was within the range found by Kamb and others (1985) to underlie Variegated Glacier, Alaska, while it was in full surge but Black Rapids Glacier was not surging. This result implies that at least localized high subglacial water pressures are typical of Black Rapids Glacier (and, by implication, other temperate glaciers) during late winter and early spring, and hence that high subglacial water pressures are a necessary but not a sufficient condition for rapid surge motion.

Humphrey and Raymond (1994) carried out hydraulic measurements on Variegated Glacier before, during and after the surge of 1982-83. They concluded that water storage during the surge was equivalent to a layer about $1 \mathrm{~m}$ thick per unit area of bed, and that much of it was stored englacially. They went on to say: "This implies a strong relationship between sliding and water storage. Furthermore, the volume of storage implies that the relationship between sliding and the basal hydrologic system is between sliding and volume of water, not necessarily between sliding and basal water pressure." In addition, they concluded that: "The volume of water stored above the surge front was the major hydraulic control on the surge." These findings suggest that if the subglacial water pressure is high but the amount of water at the bed is small, fast basal motion may not occur, necessarily, because the ice may be restrained by bed irregularities, while if the amount of water at the bed is large, fast basal motion is likely to occur because the ice is effectively separated from, and therefore not restrained by, the bed irregularities. (In the latter case, the subglacial water pres-

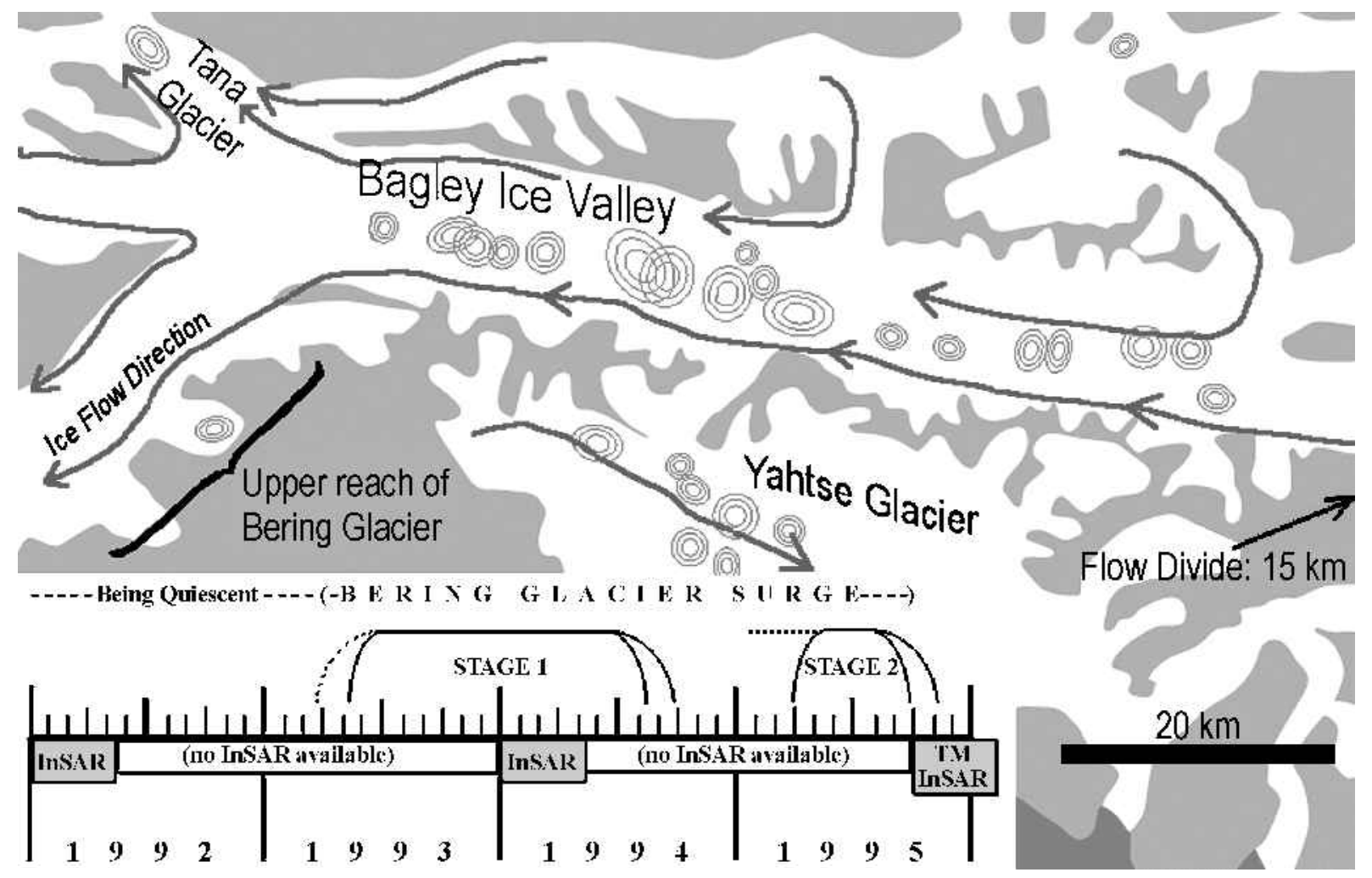

Fig. 3. Distribution of phase bull'-eyes observed on Bagley Ice Valley during January-February 1994, while it was in surge. Note that a lesser number of phase bull'-eyes were also observed during this time period on nearby non-surging glaciers. The scale at the bottom shows the ERS-1 time periods during which the orbit geometry was suitable for interferometric SAR observations. ( Adapted from Fatland and Lingle, 2002.) 
sure would presumably be high as well.) These findings also suggest that englacially stored water was acting as the source which maintained adequate water volume at the bed.

The conclusions of Humphrey and Raymond (1994) are consistent with the April 1996 observations of W. D. Harrison, M. Truffer, K. A. Echelmeyer and others (personal communication, 1997) on Black Rapids Glacier, in which high subglacial water pressures per se were not accompanied by fast basal motion.

\section{BERING GLAGIER SURGE: EVIDENGE OF MID- WINTER SUBGLAGIAL HYDRAULIG ACTIVITY}

Roush and others (2003) identified the earliest evidence that the 1993-95 surge of Bering Glacier was in progress in an ERS-1 SAR image acquired on 26 March 1993. From its apparent area of initiation, roughly $50-60 \mathrm{~km}$ up-glacier from the calving front, the surge propagated both downglacier to the terminus (Roush, 1996) and up-glacier into Bagley Ice Valley (Fatland, 1998). The acceleration of Bagley Ice Valley was "smooth" enough to yield coherence between SAR images obtained along a 3 day exact-repeat orbit. This enabled use of SAR interferometry to make high-resolution measurements of horizontal velocity prior to the surge, during winter 1992, and velocity, acceleration and vertical motion events while the surge was in full progress, during January-February 1994 (Fatland and Lingle, 1998, 2002).

Circular motion anomalies termed phase bull's-eyes, typically about $0.5-4 \mathrm{~km}$ in diameter, emerged as unexpected and significant features of the interferometric analysis (Fig. 2; see also Fatland and Lingle, 1998, fig. 17). The distribution of phase bull's-eyes observed along Bagley Ice Valley during January-February 1994 is shown in Figure 3. (These were not all observed simultaneously.) These anomalies have been described and discussed in detail by Fatland and Lingle (1998, 2002).

The simplest and most straightforward interpretation of the phase bull's-eyes, given their roughly circular, spatially localized and transient nature, is that they represented vertical motions of the glacier surface caused by subglacial hydraulic phenomena. The vertical motions indicated by the fringes were about $3-30 \mathrm{~cm}$ during the 3 day observation intervals. Phase bull's-eyes with positive and negative phase curvature were observed with about equal frequency on Bagley Ice Valley; the distribution shown in Figure 3 represents roughly equal numbers of upward and downward motion events duringJanuary-February 1994 (Fatland and Lingle, 2002).

Figure 2 shows a prominent phase bull's-eye on Tana Glacier (a Bering distributary that flows north (see Fig. 3)), having negative phase curvature indicating downward displacement. Tana is not a surge-type glacier, so this shows that mid-winter phase bull's-eyes were not observed only on the surging main trunk of Bagley Ice Valley and on the postsurge main trunk of Bering Glacier (Fatland and Lingle, 2002). Figure 3 shows that phase bull's-eyes were also observed on other glaciers that were not in a state of surge, although there were far fewer of them. Fatland (1998) also observed a prominent mid-winter phase bull's-eye on Black Rapids Glacier, which persisted long enough to show evidence of down-glacier flow. The implication is that the midwinter subglacial hydraulic activity represented by transient phase bull's-eyes is common to many temperate glaciers, but is much more vigorous when a glacier is in surge.
The phase bull's-eyes observed on Bagley Ice Valley during mid-winter 1993/94 while it was in full surge could not have resulted from direct drainage of surface water to the bed. The bull's-eyes thus imply transient delivery of englacially stored water to the bed at discrete locations. If this water originated at the surface up-glacier from a given bull's-eye during the previous late summer or autumn, this would provide the necessary hydraulic head for lifting (in effect, hydraulic jacking) of the glacier at the location of the bull's-eye. Lifting of glacier surfaces due to downward movement of surface meltwater after the onset of spring ablation has been observed on many glaciers (e.g. Iken and others, 1983; for a recent description see Mair and others, 2001). Fatland and Lingle $(1998,2002)$ show that this phenomenon also occurs during mid-winter.

\section{A SURGE HYPOTHESIS}

We propose that englacial storage of water is the fundamental driver of temperate-glacier surges, and suggest that the surge cycle can be described as follows. We begin by supposing that a surge of a glacier such as Bering Glacier-Bagley Ice Valley has run to completion, and the quiescent phase has begun.

(1) During each subsequent year the upper glacier thickens, while ablation reduces the thickness of the lower glacier, particularly near the terminus. Simultaneously, the surge-advanced terminus retreats.

(2) During late summer/early autumn of each year, after the end of the main summer melt season, the relatively small amounts of additional water generated by occasional ablation and rainfall are forced into storage, as described by Tangborn and others (1975), along with water from the firn reservoir (Fountain, 1989). This water is added to the large volumes of water already trapped within the glacier's "slow" drainage system (Raymond and others, 1995) by constriction of the passageways, due to the combination of glaciostatic pressure and reduced water flux.

(3) Simultaneously the basal motion, and hence the surface velocity, decreases significantly. We speculate that this may occur because the amount of water at the bed and the subglacial water pressure are both reduced during autumn due to most of the water within the "fast" drainage system (Raymond and others, 1995) running out to the terminus and being lost as runoff.

(4) As winter progresses, the large reservoir of englacially stored water moves downward toward the bed. This occurs for the simple reason that water is denser than ice. See, for instance, Weertman (1973) and Fountain and Walder (1998). Raymond and Harrison (1986) refer to this downward water movement as "pumping".

(5) The heterogeneous nature of the slow englacial drainage system (or what remains of it, after winter constriction of the passageways) causes water to reach the bed at discrete locations, causing subtle upward bulging of the surface on the order of several to a few tens of centimeters. Hydraulic head sufficient for lifting of the glacier may result from water reaching the bed that has originated farther up-glacier, at a higher elevation. An observer acquiring repeat-pass SAR images of the glacier at this time would see this phenomenon as a phase bull's-eye 

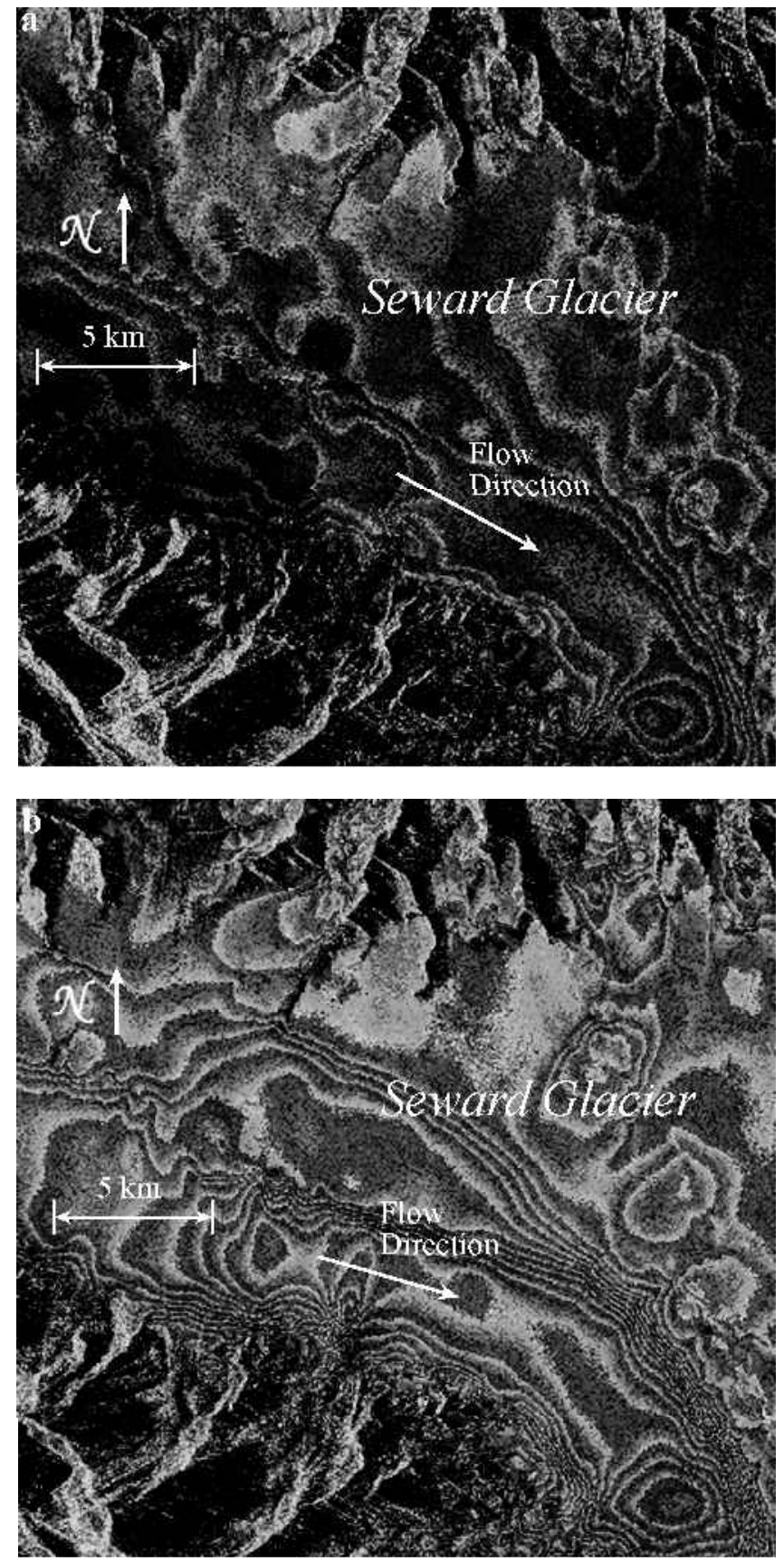

Fig. 4. (a) An interferogram of upper Seward Glacier, synthesized from SAR images acquired 21-22 October 1995. This area is located east (right) of the eastern (right) margin of Figure 3. The fringes at lower right (southeast) indicate that the main-trunk glacier was flowing at about $0.4 \mathrm{md}^{-1}$ relative to an adjacent low rock ridge. (b) An interferogram of the same area of upper Seward Glacier, synthesized from SAR images acquired 28-29 March 1996. The increased number of fringes at lower right (southeast) show that the main trunk glacier was flowing at about $1.1 \mathrm{md}^{-1}$ at this time relative to the adjacent low rock ridge. The $\sim 2.8 \times$ increase of the surface velocity between October 1995 and March 1996 suggests increased basal motion due to downward movement of englacially stored water during the winter.

with upward phase curvature. (Single-pass SAR interferometry does not permit discrimination of the subtle horizontal motion anomalies that may also be associated with uplift.)

(6) In addition, basal water may migrate horizontally, conceivably, through what remains of the constricted winter subglacial drainage system. Transient pooling of this water due to blockage at a particular location could also cause subtle upward bulging of the surface, conceivably - given adequate hydraulic head - which would be observed as a phase bull's-eye with upward phase curvature. Alternatively, drainage of a transient pool due to continued horizontal migration, after overcoming the local blockage, might be observed in an interferogram as a bull's-eye with negative phase curvature.

(7) Meanwhile, the surface velocity gradually increases as winter progresses. This phenomenon, which has been observed on Black Rapids Glacier (personal communication from W. D. Harrison, M. Truffer, and K. A. Echelmeyer, 1997), as well as on other glaciers, implies that basal motion is gradually increasing. The most straightforward explanation for this, we suggest, is that the amount of water at the bed gradually increases during winter due to continued downward movement of the water within the englacial storage reservoir. Figure $4 \mathrm{a}$ and $\mathrm{b}$, consisting of interferograms synthesized from SAR images acquired on 21-22 October 1995 (Fig. 4a) and 28-29 March 1996 (Fig. 4b), illustrate this phenomenon on upper Seward Glacier in the Saint Elias Mountains. (This area is east (right) of the eastern (right) margin of Figure 3.) The fringes in Figure $4 \mathrm{a}$, at lower right, indicate that the main-trunk Seward Glacier was flowing at about $0.4 \mathrm{~m} \mathrm{~d}^{-1}$ relative to the adjacent low rock ridge in late October 1995. The increased number of fringes at lower right in Figure $4 \mathrm{~b}$ indicates that the main-trunk Seward Glacier was flowing at about $1.1 \mathrm{~m} \mathrm{~d}^{-1}$ in the same area during late March 1996. The flow of upper Seward Glacier thus clearly accelerated during the course of the winter. Simultaneously (in the case of Black Rapids and other glaciers, possibly including Seward Glacier), the subglacial water pressures become high and steady during late winter and early spring due to slow but steady water input to the bed, combined with absence of a free and easy means for this water to drain to the terminus.

(8) The glacier, however, does not surge. This is, we suggest, because the slowly increasing volume of water at the bed is able to leak down-glacier without destabilizing the constricted subglacial drainage system of winter. The movements of this water during and after reaching the bed are expressed as relatively infrequent phase bull'seyes in SAR interferograms, as noted above (Fig. 2).

(9) In the spring, the rapidly rising hydraulic head caused by the onset of surface melting, while the winter drainage system is still constricted, causes additional water to be forced into storage (Tangborn and others, 1975). This process can continue into early summer (Stenborg, 1970) while the efficient summer drainage system, including the fast components, is gradually melting open. Finally, englacially stored water is added to the runoff from surface ablation and rainfall, causing a substantial addition to the mid-summer runoff. All of the englacially stored water probably does not run off during summer, however, and indeed only a small fraction of it may run off. Retention of much of the stored water is, we suggest, likely to be caused by the existence of the slow drainage system which continues to hold about $80-90 \%$ of the glacier's total water (in the case of Black 
Rapids Glacier (Raymond and others, 1995)), and which forms a slowly moving reservoir that will be augmented, once again, by water storage during the subsequent late summer and early autumn.

(10) Each year this cycle repeats itself. The average time required for a given glacier to return to its pre-surge thickness distribution is, we suggest, determined by the surface mass balance, with glaciers in high-precipitation regimes having, on average, shorter surge periods. As the glacier thickens toward its pre-surge geometry, its water-storage capacity increases, because for a given porosity a thicker glacier can store more water. If the surface meteorological conditions resulting in englacial water storage were the same each year, this would result in prog ressively more water descending to the bed each winter and "leaking off". The glacier would surge, presumably, in a year when the rate of water reaching the bed became large enough (due to the annually increasing reservoir of englacially stored water) to finally overwhelm the constricted winter subglacial drainage system, thus forcing pervasive failure of the subglacial till (see Clarke, 1987; Truffer and others, 2000) or, alternatively, widespread and rapid basal sliding (see Kamb, 1987; Raymond, 1987).

(11) However, the surface meteorological conditions that are favorable for englacial water storage are far from constant. Indeed, these conditions vary stochastically from year to year. A surge-type glacier thus attains, potentially, sufficient water-storage capacity for its next surge by thickening to its pre-surge geometry, but this is only one of at least two requirements. A second requirement that is, we suggest, more important is for the glacier to actually store enough water englacially for the gradual downward migration of this water during winter to finally overwhelm the constricted basal drainage system. This is, we propose, the cause of surge onset in a particular year, given that the glacier has otherwise attained its pre-surge thickness distribution. It is this large storage-capacity requirement, we suggest, that accounts for the statistical finding of Clarke and others (1986) that "long" glaciers are more likely to be surgetype than "short" glaciers. The connection is that long glaciers are, on average, likely to have lower surface slopes, and thus to be thicker and hence capable of storing more water than short glaciers.

The problem of whether sufficiently large englacial water storage can occur in 1 year as a result of favorable surface meteorological conditions (mass balance), or whether the surface meteorological conditions must be favorable over a multi-year time period, is open to question. Here we propose that the specific result must be englacial storage of a sufficiently large quantity of water, and that the interannual variability of weather and mass balance results, at some point, in this required storage actually occurring. After the 1957-60 major surge of Bering Glacier-Bagley Ice Valley, for example, a second major surge occurred in 1965-67, after only 5 years of quiescence (Post, 1972). The next major surge did not occur until 1993-95, after 26 years of quiescence. In between, however, a false start (a partial surge) occurred in 1981 (personal communication from A. Post, 1993), after 14 years of quiescence. The variability of the timing of surge onset is thus so large that the surge period must be viewed as having a large stochastic component. We propose that the stochastic timing of surge onset for a particular glacier, such as Bering Glacier-Bagley Ice Valley, is caused by the uncertainty of the meteorological conditions that must be satisfied for sufficiently large storage of englacial water to occur.

The two-phase nature of some surges demonstrates that the total englacially stored water volume involved in initiation and sustaining of these surges can be very large. That is, after cessation of the first phase, as in the cases of Variegated Glacier in 1982 (Kamb and others, 1985) and Bering Glacier in 1993-94 (Roush and others, 2003), sufficient englacially stored water remained to initiate and sustain a second phase, even though both of these glaciers had been drawn down from their pre-surge configurations. In the case of Bering Glacier, the fast motion of the first phase ended with a large outburst of sediment-laden water that began 27 July 1994 and lasted at least 2 weeks (personal communication from B. F. Molnia, 1994). Renewed terminus advance was observed in April 1995, which appeared to cease in July 1995 (personal communication from S. Ranney, 1995). An outburst flood of sediment-laden water occurred in midSeptember 1995, which lasted approximately 10 or 11 days (Roush, 1996; Roush and others, 2003). This, we suggest, illustrates the critical role of englacially stored water above and beyond the glacier having a particular pre-surge thickness distribution. We also suggest that the partial Bering Glacier surge of 1981 (personal communication from A. Post, 1993) may have been a result of surface meteorological conditions causing sufficient englacial water storage to initiate a surge, but not enough to sustain it. We note also, as pointed out by M.J. Sharp (personal communication, 2002), that intensive surface and englacial fracturing of a glacier during the first phase of a surge may cause an increase in englacial water storage sufficient to initiate a second phase, due to an increase in the amount of surface area available for melting and a large increase in the number of conduits (i.e. crevasses) whereby water can flow downward into englacial storage.

\section{SUMMARY}

A surge hypothesis is presented that builds on the work of Stenborg (1970), Björnsson (1972), Tangborn and others (1975), and more recent studies (e.g. Collins, 1982; Willis and others, 1993; Murray and others, 2000) which have shown that temperate glaciers seasonally store water englacially, and the surge observations and hypotheses of Kamb and others (1985), Raymond and Harrison (1986), Kamb (1987) and Raymond (1987). Our hypothesis also builds on (i) the hydraulic study of Humphrey and Raymond (1994), which showed that basal motion is a function of the amount of water at the bed, not just the subglacial water pressure; (ii) the work of Raymond and others (1995), which showed that glacier drainage can be represented as consisting of superimposed fast and slow drainage systems; (iii) the deep-drilling observations of W. D. Harrison, M. Truffer, K. A. Echelmeyer and others (personal communication, 1997), which showed that Black Rapids Glacier is characterized by high and steady subglacial water pressures during late winter; and (iv) the space-borne interferometric SAR observations of Fatland (1998) and Fatland and Lingle (1998, 2002), which revealed evidence of vigorous subglacial hydraulic activity beneath Bagley Ice Valley during mid-winter 1993/94, a time 
when it was in full surge and when this water could not have resulted from direct drainage from the surface.

Englacial storage of a sufficiently large volume of water, after surge-type glaciers have thickened sufficiently to store this water, is proposed as the cause of temperate-glacier surges. The average time required to return a given glacier to its pre-surge geometry appears to be a function of its mass balance, i.e. the regional climate, with glaciers in high-precipitation regimes surging more frequently, on average, than glaciers in low-precipitation regimes. Downward movement of stored water to the bed during winter, at a rate sufficient to finally overwhelm the constricted subglacial drainage system, is proposed as the process that results in surge initiation, consisting of pervasive failure of the subglacial till or, alternatively, the onset of widespread and rapid basal sliding. It follows that "long" glaciers are more likely to be surge-type than "short" glaciers, as determined by Clarke and others (1986), because long glaciers are likely to be thicker and hence capable of storing more water than short glaciers. It also follows that glaciers do not surge that have sufficient subglacial drainage capacity during winter to allow englacially stored water to "leak off" down-glacier as it descends to the bed, without overwhelming the basal drainage system. In addition, it follows that a surge-type glacier will not actually surge, given that it is otherwise primed by having attained its pre-surge thickness distribution, until the surface meteorological conditions occur that result in englacial storage of a sufficiently large volume of water. We propose that the uncertainty of these meteorological conditions accounts for the stochastic timing of surge onset for a given surge-type glacier.

\section{AGKNOWLEDGEMENTS}

We thank the NASA Cryospheric Sciences Program for supporting this work with grants NAG5-8769 and NAG5-11336, M. J. Sharp, G. E. Flowers and an anonymous reviewer for reviews that improved the manuscript, $\mathrm{H}$. Björnsson for his assistance as Scientific Editor, and J. Weertman, W. D. Harrison, M. Truffer and K. A. Echelmeyer for valuable discussions and comments.

\section{REFERENGES}

Björnsson, H. 1972. Bægisárjökull, north-Iceland. Results of glaciological investigations 1967-1968. Part 2. The energy balance. Fökull, 22, 44-61.

Björnsson, H. 1998. Hydrological characteristics of the drainage system beneath a surging glacier. Nature, 395(6704), 771-774.

Clarke, G. K. C. 1987. Subglacial till: a physical framework for its properties and processes. F. Geophys. Res., 92(B9), 9023-9036.

Clarke, G. K. C., S. G. Collins and D. E. Thompson. 1984. Flow, thermal structure, and subglacial conditions of a surge-type glacier. Can. F. Earth Sci., 21 (2), 232-240.

Clarke, G. K. C., J. P. Schmok, C. S. L. Ommanney and S. G. Collins. 1986. Characteristics of surge-type glaciers. F. Geophys. Res., 91(B7), 7165-7180.

Collins, D. N. 1982. Water storage in an Alpine glacier. International Association of Hydrological Sciences Publication 138 (Symposium at Exeter 1982 - Hydrological Aspects of Alpine and High Mountain Areas), 113-122.

Fatland, D. R. 1998. Studies of Bagley Icefield during surge and Black Rapids Glacier, Alaska, using spaceborne SAR interferometry. (Ph.D. thesis, University of Alaska Fairbanks.)
Fatland, D. R. and C. S. Lingle. 1998. Analysis of the 1993-95 Bering Glacier (Alaska) surge using differential SAR interferometry. f. Glaciol., 44(148), $532-546$.

Fatland, D. R. and C. S. Lingle. 2002. InSAR observations of the 1993-95 Bering Glacier (Alaska, U.S.A.) surge and a surge hypothesis. F. Glaciol., 48(162), 439-451.

Flowers, G. E. 2000. A multicomponent coupled model of glacier hydrology. (Ph.D. thesis, University of British Columbia.)

Flowers, G. E. and G. K. C. Clarke. 1999. Surface and bed topography of Trapridge Glacier, Yukon Territory, Canada: digital elevation models and derived hydraulic geometry. f. Glaciol., 45(149), 165-174.

Fountain, A. G. 1989. The storage of water in, and hydraulic characteristics of, the firn of South Cascade Glacier, Washington State, U.S.A. Ann. Glaciol., 13, 69-75.

Fountain, A. G. and J. S. Walder. 1998. Water flow through temperate glaciers. Rev. Geophys., 36(3), 299-328.

Humphrey, N. F. and C. F. Raymond. 1994. Hydrology, erosion and sediment production in a surging glacier: Variegated Glacier, Alaska, 1982-83. 7. Glaciol., 40(136), 539-552.

Iken, A., H. Röthlisberger, A. Flotron and W. Haeberli. 1983. The uplift of Unteraargletscher at the beginning of the melt season - a consequence of water storage at the bed? F. Glaciol., 29 (101), 28-47.

Kamb, B. 1987. Glacier surge mechanism based on linked cavity configuration of the basal water conduit system. F. Geophys. Res., 92(B9), 9083-9100.

Kamb, B. and 7 others. 1985. Glacier surge mechanism: 1982-1983 surge of Variegated Glacier, Alaska. Science, 227(4686), 469-479.

Mair, D., P. Nienow, I. Willis and M. Sharp. 2001. Spatial patterns of glacier motion during a high-velocity event: Haut Glacier d'Arolla, Switzerland. 7. Glaciol., 47(156), 9-20.

Molnia, B. F. and A. Post. 1995. Holocene history of Bering Glacier, Alaska: a prelude to the 1993-1994 surge. Phys. Geogr., 16(2), 87-117.

Murray, T., G.W. Stuart, M. Fry, N. H. Gamble and M. D. Crabtree. 2000. Englacial water distribution in a temperate glacier from surface and borehole radar velocity analysis. 7. Glaciol., 46(154), 389-398.

Post, A. 1972. Periodic surge origin of folded medial moraines on Bering piedmont glacier, Alaska. f. Glaciol., 11 (62), 219-226.

Raymond, C. F. 1987. How do glaciers surge? A review. 7. Geophys. Res., 92(B9), 9121-9134.

Raymond, C. F. and W. D. Harrison. 1986. Winter initiation of surges. [Abstract.] Eidg. Tech. Hochschule, Zürich. Versuchsanst. Wasserbau, Hydrol. Glaziol. Mitt., 90, 85-86.

Raymond, C. F., R. J. Benedict, W. D. Harrison, K. A. Echelmeyer and M. Sturm. 1995. Hydrological discharges and motion of Fels and Black Rapids Glaciers, Alaska, U.S.A.: implications for the structure of their drainage systems. F. Glaciol., 41 (138), 290-304.

Röthlisberger, H. and H. Lang. 1987. Glacial hydrology. In Gurnell, A. M. and M. J. Clark, eds. Glacio-fluvial sediment transfer: an alpine perspective. Chichester, etc., John Wiley and Sons, 207-284.

Roush, J. J. 1996. The 1993-94 surge of Bering Glacier, Alaska, observed with satellite synthetic aperture radar. (M.Sc. thesis, University of Alaska Fairbanks.)

Roush, J.J., C. S. Lingle, R. M. Guritz and D. R. Fatland. 2003. Surge-front propagation and velocities during the early-1993-95 surge of Bering Glacier, Alaska, from sequential SAR imagery. Ann. Glaciol., 36 (see paper in this volume)

Stenborg, T. 1970. Delay of run-off from a glacier basin. Geogr. Ann., 52A(1), 1-30.

Tangborn, W.V., R. M. Krimmel and M. F. Meier. 1975. A comparison of glacier mass balance by glaciological, hydrological and mapping methods, South Cascade Glacier, Washington. International Association of Hydrological Sciences Publication 104 (Symposium at Moscow 1971 - Snow and Ice), 185-196.

Truffer, M., R. J. Motyka,W. D. Harrison, K. A. Echelmeyer, B. Fisk and S. Tulaczyk. 1999. Subglacial drilling at Black Rapids Glacier, Alaska, U.S.A.: drilling method and sample descriptions. F. Glaciol., 45(151), 495-505.

Truffer, M., W. D. Harrison and K. A. Echelmeyer. 2000. Glacier motion dominated by processes deep in underlying till. f. Glaciol., 46(153), 213-221.

Weertman, J. 1973. Can a water-filled crevasse reach the bottom surface of a glacier? International Association of Scientific Hydrology Publication 95 (Symposium at Cambridge 1969 - Hydrology of Glaciers ), 139-145.

Willis, I. C., M. J. Sharp and K. S. Richards. 1993. Studies of the water balance of Midtdalsbreen, Hardangerjökulen, Norway: 2. Water storage and runoff prediction. Z. Gletscherkd. Glazialgeol., 27-28, 1991-1992, 117-138. 